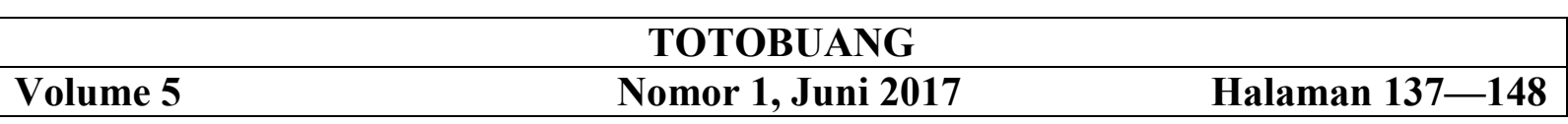

\title{
MOTIF DAN TIPE DALAM CERITA RAKYAT KEPULAUAN ARU (Type and Motive in Aru Island Folklore)
}

\author{
Nita Handayani Hasan \\ Kantor Bahasa Maluku \\ Jalan Mutiara No. 3A, Mardika, Ambon \\ Pos-el: nita.handayani@kemdikbud.go.id \\ (Diterima: 13 April 2017; Direvisi: 22 Mei 2017; Disetujui: 5 Juni 2017)
}

\begin{abstract}
The collection of folklore in Indonesia is an interesting thing to do. It can shows the cultural wealth, and grows up the pride of nation's folklore varieties. The folklor inventorization has bene rarely done in Kepulauan Aru district, Mollucas province. It'sbecause the villages in Aru's island has been separated by the sea and difficult to be reached. This research discussed about type and motif of a few folklore in Kepulauan Aru district.. The purpose of this research were finding out the folklore which had invented before, and clasifyed them in type and motive. The metode wasqualitative analyzing. The result found that there were nine folklores which has invented, four types, and four motives.
\end{abstract}

Keywords: type, motive, Aru archipelago Hal tersebut dapat menunjukkan kekayaan budaya bangsa, dan menumbuhkan rasa bangga terhadap keanekaragaman kekayaan sastra lisan nasional. Inventarisasi sastra lisan di Kabupaten Kepulauan Aru, Provinsi Maluku hingga saat ini masih jarang dilakukan. Hal tersebut dikarenakan desa-desa di Kabupaten Kepulauan Aru masih sulit dijangkau karena dipisahkan oleh lautan. Walaupun demikian, penelitian ini mencoba mengangkat beberapa cerita rakyat dari Kabupaten Kepulauan Aru yang telah terinventarisasi untuk kemudian dikelompokkan dalam tipe dan motif. Tujuan dari adanya penelitian ini, yaitu untuk mengetahui cerita-cerita rakyat apa saja yang telah terinventarisasi, dan termasuk dalam tipe dan motif apa sajakah ceritacerita rakyat tersebut. Metode yang digunakan yaitu analisis kualitatif. Setelah melakukan pengamatan, hasil yang diperoleh, yaitu terdapat sembilan cerita rakyat yang terinventarisasi, empat tipe dan empat motif cerita.

Kata-kata kunci: tipe, motif, Kepulauan Aru.

\section{PENDAHULUAN}

Keberadaan sastra lisan yang ada di Indonesia merupakan kekayaan bangsa yang harus terus dilestarikan. Melalui sastra lisan, generasi muda dapat mengetahui sejarah, adat-istiadat dan kebudayaan di tempat tinggalnya. Pelestarian terhadap sastra lisan dapat dilakukan dengan perekaman, inventarisasi, dan pendokumentasian sastrasastra lisan yang ada di suatu daerah.

Proses pendokumentasian sastra lisan di Indonesia bukan merupakan hal yang mudah. Mengingat wilayah Negara Indonesia yang terdiri atas gugusan pulau. Oleh karena itu, diperlukan peran masyarakat dan pemerintah untuk bersamasama melestarikan dan menjaga keberadaan sastra lisan. Pelestarian sastra lisan dapat menunjukkan kekayaan budaya bangsa, dan menumbuhkan rasa bangga terhadap keanekaragaman kekayaan sastra lisan nasional.

Sastra lisan yang ada di Indonesia memiliki keberagaman bentuk dan motif. Keberagaman tersebut dapat menunjukkan dua hal, yaitu kekayaan ragam sastra lisan yang ada di Indonesia, dan semakin mempererat keutuhan dan kesatuan bangsa. Setiap daerah yang ada di Indonesia memiliki kekhasan dalam sastra lisan. Namun terkadang terdapat persamaan antara satu sastra lisan yang ada di suatu daerah dan daerah lainnya. Adanya persamaanpersamaan yang muncul dapat dijadikan 
dasar untuk mempererat keutuhan dan kesatuan bangsa.

Melalui inventarisasi sastra lisan berdasarkan bentuk dan motif, dapat diketahui dengan mudah persamaan dan perbedaan sastra-sastra lisan Nusantara. Sehingga diharapkan mampu memperoleh jejak kekerabatan daerah-daerah di Nusantara. Hal tersebut tentunya akan mendorong penguatan Negara Kesatuan Republik Indonesia. Diharapkan tidak ada lagi daerah-daerah yang diklaim milik negara tetangga dan berpisah dari Negara Kesatuan Republik Indonesia.

Kegiatan inventarisasi sastra lisan telah dilakukan oleh para peneliti yang ada di Eropa. Mereka melakukan pengumpulan sastra rakyat yang ada di Eropa Barat, Selatan, dan Timur. Mereka mengupayakan dilakukannya sebuah usaha raksasa untuk mengumpulkan, mengklasifikasikan, dan membandingkan cerita rakyat selengkap dan seluas mungkin, bahkan menjangkau ke seluruh dunia (Taum, 2016:5). Puluhan ribu cerita rakyat yang diperoleh kemudian dikumpulkan, diklasifikasikan, dan disusun sedemikian rupa sehingga perbandingan dan penelusuran sejarah setiap cerita rakyat dimungkinkan.

Provinsi Maluku sebagai salah satu provinsi kepulauan yang ada di Indonesia banyak memiliki warisan budaya lokal berupa sastra lisan yang unik untuk diteliti. Provinsi Maluku terdiri dari sebelas kabupaten dan kota, yaitu Kota Ambon, Kota Tual, Kabupaten Maluku Tengah, Kabupaten Seram Bagian Barat, Kabupaten Seram Bagian Timur, Kabupaten Kepulauan Aru, Kabupaten Maluku Tenggara, Kabupaten Maluku Tenggara Barat, Kabupaten Maluku Barat Daya, Kabupaten Buru, dan Kabupaten Buru Selatan. Letak geografis Provinsi Maluku yang terdiri atas berbagai pulau-pulau kecil juga akan memberikan keunikan tersendiri dalam isi maupun persebaran cerita-cerita rakyat.

Wilayah Provinsi Maluku yang terdiri dari gugusan pulau dapat dikatakan sebagai miniatur Negara Kesatuan Republik Indonesia. Desa-desa yang ada di kabupaten dan kota memiliki kekhasan tradisi lisan. Namun demikian terdapat satu falsafat lokal yang mengikat persaudaraan antar wilayah yang ada di Maluku. Filsafat tersebut ialah patasiwa dan patalima. Filsafat hidup patasiwa (kelompok sembilan) patalima (kelompok lima) diketahui melalui ceritacerita rakyat yang ada di Maluku. Tidak menutup kemungkinan bahwa filsafat hidup patasiwa dan patalima ada di daerah lain di Indonesia.

Kabupaten Kepulauan Aru adalah salah satu kabupaten di Provinsi Maluku yang memiliki keanekaragaman sastra lisan. Keanekaragaman sastra lisan yang ada, mungkin saja memiliki persamaan dengan wilayah lainnya di Indonesia. Jenis-jenis sastra lisan yang ada di Kabupaten Kepulauan Aru, yaitu berupa cerita rakyat, nyanyian rakyat, dan kepercayaan rakyat. Cerita-cerita rakyat yang terdapat di Kabupaten Kepulauan Aru umumnya memiliki motif asal-usul keberadaan suatu tempat, dan nama-nama desa. Motif tersebut juga mungkin akan ditemukan di daerah lainnya. Adanya persamaan bentuk dan motif cerita rakyat di satu daerah dengan daerah lainnya di Indonesia menunjukkan keanekaragaman dan kekayaan sastra lisan Nusantara.

Berdasarkan latar belakang masalah yang telah diuraikan, maka permasalahan yang akan dibahas dalam penelitian ini sebagai berikut (1) apa saja cerita rakyat yang terdapat di Kabupaten Kepulauan Aru? (2) termasuk dalam tipe apa cerita-cerita rakyat yang ada di Kabupaten Kepulauan Aru? (3) bagaimana motif di dalam ceritacerita rakyat yang ada di Kabupaten Kepulauan Aru?

Secara khusus penelitian ini bertujuan untuk (1) menginventarisasi ceritacerita rakyat yang terdapat di Kabupaten Kepulauan Aru, (2) mengetahui tipe-tipe yang termasuk dalam cerita-cerita rakyat yang ada di Kabupaten Kepulauan Aru, (3) 
mengetahui motif-motif yang terkandung dalam cerita-cerita rakyat di Kabupaten Kepulauan Aru.

\section{LANDASAN TEORI \\ Sastra Lisan}

Sastra lisan (oral literature) adalah bagian dari tradisi lisan (oral tradition) atau yang biasanya dikembangkan dalam kebudayaan lisan (oral culture) berupa pesan-pesan, cerita-cerita, atau kesaksiankesaksian ataupun yang diwariskan secara lisan dari satu generasi ke generasi yang lainnya (Vansina dalam Taum (2010:10). Pesan, cerita, atau kesaksian-kesaksian tersebut disampaikan melalui tuturan atau nyanyian, dalam bentuk-bentuk seperti dongeng, peribahasa, balada, atau puisi (Taum, 2011:10).

Menurut Zaimar dalam Pudentia (2015:374), sastra lisan adalah semua cerita yang sejak awalnya disampaikan secara lisan, tidak ada naskah tertulis yang dapat dijadikan pegangan. Bentuknya dapat beraneka ragam, misalnya berupa puisi, drama, maupun prosa. Kebiasaan masyarakat Indonesia dalam pewarisan nilainilai budaya melalui cara lisan menjadikan keberadaan sastra lisan di Indonesia sangat beragam. Setiap daerah memiliki berbagai istilah-istilah untuk menyebut kebiasaan bertutur dalam upacara-upacara adat. Di Maluku dikenal istilah Kapata untuk menyebut nyanyian rakyat-nyanyian rakyat yang ada di Maluku Tengah. Nyanyiannyanyian rakyat tersebut pada awalnya tidak memiliki teks tulis, dan hanya dituturkan.

Pengungkapan sastra lisan dalam masyarakat selalu dikaitkan dengan kreativitas yang menakjubkan. Para leluhur kita mencoba menggunakan cara-cara yang kreatif dan menyenangkan untuk mewariskan kebudayaan-kebudayaan yang mereka miliki. Keterbatasan akses terhadap kertas dan alat tulis merupakan faktor pendukung. Hanya orang-orang terpelajar yang gampang memperoleh alat tulis. Oleh karena itu, kebiasaan bertutur merupakan solusi yang tepat dalam mewariskan nilainilai budaya.

Dalam sastra lisan terkandung makna-makna simbolis, metaforis, dan bersifat estetis. Unsur estetika bukanlah hal yang ditonjolkan dan dipentingkan. Para leluhur berseni dan bersastra untuk menghayati dimensi transedensnya, sambil menyampaikan peristiwa eksistensial mengenai realita-realita besar dalam kehidupan manusia, seperti kelahiran, kehidupan, kesakitan, ketakutan, pendambaan keselamatan, dan permohonan mengatasi maut. Itu semua diungkapkan dalam gerak yang simbolis, dalam bahasa yang berwibawa, dan kesadaran partisipasi.

\section{Cerita Rakyat}

Dari semua bentuk folklor, yang paling banyak diteliti para ahli folklor adalah cerita prosa rakyat. Menurut William R. Boscom dalam Danandjaja (2007:50), cerita prosa rakyat dapat dibagi dalam tiga golongan besar, yaitu (1) mite (myth), (2) legenda (legend), dan (3) dongeng (folkale).

Mite merupakan cerita rakyat yang dianggap suci oleh yang empunya cerita. Tokoh dalam cerita yang merupakan mite adalah para dewa atau makhluk setengah dewa. Peristiwa terjadi di dunia lain atau bukan di dunia yang kita sekarang. Mite merupakan cerita yang terjadi pada masa lampau.

Mite di Indonesia biasanya menceritakan terjadinya alam semesta, terjadinya susunan para dewa, dunia dewata, terjadinya manusia pertama dan tokoh pembawa kebudayaan, terjadinya makanan pokok, seperti beras dan sebagainya, untuk pertama kali.

Legenda merupakan cerita rakyat yang mirip dengan mite, yaitu dianggap benar-benar terjadi tetapi tidak dianggap suci. Legenda ditokohi oleh manusia, walaupun adakalanya memiliki sifat-sifat yang luar biasa dan sering juga dibantu makhluk ajaib. Tempat terjadinya di dunia 
yang sama dengan dunia kita. Cerita yang terjadi belum terlalu lampau.

Legenda seringkali dipandang sebagai "sejarah" kolektif (folk history). Bentuk "sejarah" dalam legenda tidak tertulis dan telah mengalami distorsi, sehingga seringkali dapat jauh berbeda dengan kisah aslinya. Untuk menggunakan legenda sebagai suatu bahan untuk merekonstruksi sejarah suatu folk, maka perlu dilakukan pembersihan bagian-bagian yang mengandung sifat-sifat folklor.

Dongeng adalah cerita rakyat yang dianggap tidak benar-benar terjadi. Dongeng tidak terikat pada waktu dan tempat. Dongeng diceritakan terutama untuk hiburan, walaupun banyak juga yang melukiskan kebenaran, berisikan pelajaran (moral), atau bahkan sindiran. Dongeng biasanya mempunyai kalimat pembukaan dan penutup yang bersifat klise.

Seperti halnya mite dan legenda, dongeng juga mempunyai unsur-unsur cerita yang terdapat di daerah-daerah lain yang letaknya berjauhan, sehingga dapat dijadikan bahan penelitian perbandingan.

\section{Tipe dan Motif dalam Cerita Rakyat}

Motif dalam ilmu folklor adalah unsur-unsur suatu cerita (narrative elements). Motif teks suatu cerita rakyat adalah unsur dari cerita itu yang menonjol dan tidak biasa sifatnya. Unsur-unsur itu dapat berupa benda (seperti tongkat wasiat), hewan luar biasa (kuda yang dapat berbicara), suatu konsep (larangan atau tabu), suatu perbuatan (ujian ketangkasan), penipuan terhadap suatu tokoh (raksasa atau dewa), tipe orang tertentu (si pandir, si kabayan), atau sifat struktur tertentu (pengulangan seperti angka keramat seperti angka tiga dan tujuh) (Danandjaja, 2007:53).

Memahami tentang motif dan tipe dalam cerita rakyat dapat dilakukan juga melalui teori Madzab Finlandia yang dikemukakan oleh Taum (2011:84-91). Menurutnya, Madzab Finlandia adalah sebuah aliran kajian sastra lisan yang berkembang di Finlandia dan berpusat di ibu kota negaranya, Helsinki. Aliran ini mengembangkan metode dan teori historiskomparatif yang bersifat sistematik. Pada abad ke-19, minat utama ilmu pengetahuan lebih terarah pada penciptaan, asal-usul cerita rakyat, sesuai dengan pendekatan sejarah yang umum berlaku dalam ilmu sastra. Pada zaman itu sastra rakyat di Eropa Barat dibandingkan dengan sastra rakyat di bagian dunia lain seperti Eropa Selatan dan Eropa Timur. Studi bandingan mereka bertujuan untuk a) memperlihatkan hubungan antara berbagai sampel sastra rakyat; b) mengungkapkan pola penyebaran atau migrasi sastra rakyat itu; c) melacak dan menjelaskan tempat asal sebuah cerita rakyat; dan d) sedapat mungkin mengetahui bentuk asli sebuah cerita rakyat yang telah mengalami berbagai transformasi.

Dua kriteria dasar madzab Finlandia yaitu type dan motive. Type berarti cerita tersebut digolongkan berdasarkan tipe atau jenisnya. Berdasarkan tipe-tipenya, Aarne-Thompson membuat sistem klasifikasi dongeng yang menggolongkannya ke dalam tujuh jenis sebagai berikut.

1) Animal Tales (dongeng binatang), meliputi binatang buas (serigala yang pintar dan binatang buas lainnya), binatang buas dan binatang peliharaan, binatang buas dan manusia, binatang peliharaan, dan binatang serta objek-objek lainnya.

2) Tales of Magic (dongeng tentang halhal yang magis), meliputi tantangan supranatural, istri atau suami atau kerabat supranatural, barang-barang magis, kekuatan atau pengetahuan supranatural, dan dongeng-dongeng lainnya tentang supranatural.

3) Rigious Tales (dongeng keagamaan), meliputi imbalan hadiah atau hukuman dewa, kebenaran yang terwujud, surga, hantu, dan dongengdongeng keagamaan lainnya. 
4) Realistic Tales atau novelle (dongeng realistik), meliputi cerita-cerita seperti seorang pemuda biasa menikahi putri raja, seorang wanita biasa menikah dengan sang pangeran, bukti kesetiaan dan kemurnian, istri yang keras kepala belajar menjadi setia, prinsip-prinsip hidup yang baik, tindakan dan katakata yang cerdas, dongeng tentang nasib, perampok dan pembunuh, dan dongeng-dongeng realistik lainnya.

5) Tales of the Stupid Ogre/Giant/Devil (dongeng tentang raksasa atau hantu yang bodoh), meliputi kontrak kerja, hubungan antara manusia dan raksasa, persaingan antara manusia dan raksasa, manusia membunuh atau melukai raksasa, raksasa ditakut-takuti oleh manusia, manusia menaklukan raksasa, jiwa diselamatkan dari gangguan setan.

6) Anecdotes and Jokes (anekdot dan lelucon) meliputi: cerita-cerita tentang si pandir, cerita tentang pasangan yang sudah menikah (istrinya yang bodoh dan suaminya, suaminya yang bodoh dan istrinya), cerita tentang seorang wanita (mencari istri, lelucon tentang seorang nyonya tua), cerita tentang seorang laki-laki (pria yang cerdas, keberuntungan, lelaki bodoh), lelucon tentang tokoh-tokoh agama (tokoh agama ditipu, tokoh agama dan perihal seks), lelucon tentang kelompok masyarakat lain.

7) Formula Tales (dongeng yang memiliki formula), meliputi: dongeng-dongeng kumulatif (yang didasarkan pada jumlah, objek, binatang, atau nama; yang selalu dikaitkan dengan kematian; makanan, atau kejadian-kejadian lainnya), dongeng tentang jebakan, dan dongeng-dongeng formula lainnya.
Motif didefinisikan sebagai anasir terkecil dalam sebuah cerita yang mempunyai daya tahan dalam tradisi. Berdasarkan kriteria tersebut, mereka menyusun index atau katalogus tipe-tipe dan motif-motif yang dapat diterapkan secara universal pada cerita-cerita rakyat. Secara lebih lengkap, yang dimaksudkan motif adalah unsur-unsur suatu cerita (narrative elements). Motif teks suatu cerita rakyat adalah unsur dari carita tersebut yang menonjol dan tidak biasa sifatnya (Danandjaja dalam Taum, 2011:87-88).

Taum (2011:88) mengemukakan beberapa motif yang dapat ditemukan dalam berbagai cerita rakyat sebagai berikut.

1) Motif berupa benda, misalnya: tongkat wasiat, sapu ajaib, lampu ajaib, bunga mawar, tanah liat, benda-benda angkasa. Cerita-cerita asal-usul manusia, misalnya ada yang mengatakan manusia dibuat dari tanah liat, manusia berasal dari telur burung garuda, manusia berasal dari pohon tertentu, dan sebagainya. Hal ini berhubungan dengan keyakinan religius ataupun fauna dan flora totem.

2) Motif berupa hewan yang luar biasa, misalnya kuda yang bisa terbang, buaya siluman, singa berkepala manusia, raksasa, hewan yang bisa berbicara, burung phoenix, ular naga, ayam jantan.

3) Motif yang brupa suatu konsep, misalnya larangan atau tabu. Misalnya konsep yang menjelaskan wanita hamil tidak boleh makan pisang kembar. Mengapa seorang gadis tidak boleh makan di depan pintu. Mengapa diperlukan ritual membersihkan desa, dan sebagainya.

4) Motif berupa suatu perbuatan (uji ketangkasan minum alkohol, bertemu di gunung, turun dari gunung, menyamar sebagai fakir 
miskin, menghambakan diri, bertapa, dan sebagainya).

5) Motif tentang penipuan terhadap suatu tokoh (raksasa atau hewan).

6) Motif yang menggambarkan tipe orang tertentu, misalnya yang sangat pandai seperti Abunawas, tokoh yang selalu tertimpa nasib sial, tokoh yang bijaksana, tokoh pelaut ulung.

Menurut Taum (2011:91), dalam kajian madzab Finlandia, jika ditemukan dua motif yang sama pada dua kelompok etnis yang berbeda, maka mereka mengajukan dua pandangan teoritis yang berbeda.

1) Teori Monogenesis, yakni teori yang mengatakan bahwa motif tertentu pasti berasal dari satu daerah. Baru kemudian terjadi proses penyebaran atau difusi (diffusion).

2) Teori poligenesis, yakni teori yang berpandangan bahwa motif-motif tersebut merupakan penemuanpenemuan tersendiri yang tidak ada kaitannya atau sejajar.

\section{METODE}

Penelitian ini menggunakan metode analisis kualitatif yang dilakukan melalui beberapa tahapan. Tahap awal yaitu menentukan objek penelitian, pembuatan proposal, meyiapkan instrumen penelitian, menyusun pedoman wawancara, dan menyiapkan cara pengumpulan data. Tahap kedua yaitu melakukan pengumpulan data. Data-data yang digunakan dalam penelitian ini yaitu cerita-cerita rakyat yang ada di Kabupaten Kepulauan Aru, Provinsi Maluku, khususnya yang terdapat di Desa Longgar, Apara, Karey, Beltubur, Gomar Meti, Koba Sel Timur, Kojabi, dan Benjina. Desa-desa tersebut tersebar di kecamatan Aru Tengah Selatan, kecamatan Aru Selatan Timur, Kecamatan Aru Tengah, dan Kecamatan Aru Tengah Timur.

Sumber data penelitian ini yaitu berupa transkrip hasil wawancara dengan informan, dan salinan-salinan cerita rakyat yang diperoleh di lapangan. Cara pengumpulan data yaitu pengamatan langsung di lapangan, merekam wawancara langsung terhadap informan, mentranskripsi data hasil wawancara, mengumpulkan cerita-cerita rakyat yang telah dituliskan, dan data dukung lainnya yang ditemukan di lapangan.

Tahap ketiga yaitu melakukan klasifikasi dan identifikasi data. Data-data yang diperoleh, kemudian dikumpulkan, dan ditelaah isi dan bentuknya. Data-data tersebut selanjutnya diklasifikasikan untuk mengetahui tipe dan motif yang terkandung dalam cerita-cerita rakyat. Tahap keempat yaitu melakukan analisis terhadap data yang telah diperoleh berdasarkan teori dan metode yang telah ditentukan.

\section{PEMBAHASAN}

Berdasarkan hasil pengumpulan data dan penelitian yang dilakukan, ditemukan sembilan cerita rakyat. Kesembilan cerita rakyat tersebut kemudian digolongkan dalam beberapa tipe dan motif. Setiap cerita yang disajikan tidak menutup kemungkinan muncul beberapa kali pada tipe dan motif yang telah dijelaskan pada bagian landasan teori. Namun berikut ini penulis berusaha menyajikan hasil pengamatan, dan kemudian menggolongkan cerita-cerita yang diamati ke dalam tipe dan motif berdasarkan unsur yang dirasa paling dominan ada di dalam cerita-cerita tersebut.

\section{A. Tipe Cerita \\ 1. Cerita Rakyat Tipe Binatang (Animals Tales)}

Cerita-cerita rakyat yang termasuk dalam tipe ini yaitu cerita tentang binatang buas (serigala yang pintar dan binatang buas lainnya), binatang peliharaan, binatang buas dan manusia, binatang peliharaan, dan binatang serta objek-objeknya. Cerita rakyat yang termasuk dalam tipe ini, yaitu

1) Datuk Rar Jedau 
Cerita Datuk Rar Jedau berasal dari desa Gomu-Gomu. Cerita ini berisi kisah seorang datuk perempuan yang bernama Datuk Rar Jedau. Dia berasal dari pulau Eno Karang, dan menjelma menjadi ikan lumbalumba. Datuk tersebut bersama temantemannya mandi di pinggir pantai. Ketika sedang asyik berenang, seorang pria yang berasal dari desa Gomo-gomo menyembunyikan salah satu kulit lumbalumba yang ada di tepi pantai. Ternyata kulit yang diambil sang pemuda adalah milik Datuk Rar Jedau.

Ketika semua temannya hendak kembali ke Pulau Eno Karang, Datuk Rar Jedau tidak dapat menemukan kulitnya. Oleh karena itu, sang datuk harus tinggal di Desa Gomu-Gomu. Melihat Datuk Rar Jedau menangis sendirian di tepi pantai, laki-laki yang mengambil kulit milik Datuk Rar Jedau mengajak Datuk Rar Jedau untuk pulang ke rumahnya. Singkat cerita, keduanya kemudian menikah dan dikaruniai seorang anak laki-laki.

Seiring dengan berjalanya waktu, anak laki-laki tersebut besar dan bermain dengan anak-anak lain di Desa GomuGomu. Anak laki-laki tersebut kemudian diejek oleh anak-anak lain bahwa ibunya bukan manusia tetapi seekor ikan laut.Ejekan itu terus menerus mengakibatkan anak laki-laki itu menjadi malu. Setiba di rumahnya dia bertanya kepada ibunya apakah ibunya seekor ikan. Mendengar pertanyaan anaknya, Datuk Rar Jedau tidak dapat menjawab karena malu.

Ketika suami Datuk Rar Jedau sedang pergi ke kebun, Datuk Rar Jedau menemukan kulitnya di dalam sebuah bakul. Setelah menemukan kulit ikannya yang telah lama hilang, Datuk Rar Jedau memutuskan kembali ke Pulau Eno Karang. Ketika dia masuk ke dalam laut, dia berubah menjadi seekor lumba-lumba. Sebelum dia pergi, dia berpesan kepada anaknya untuk memberitahukan kepada ayahnya bahwa dia telah kembali ke alamnya. Dalam perjalannya menuju Pulau Eno Karang,
Datuk Rar Jedau merasa sedih dan bimbang karena telah meninggalkan anaknya. Karena perasaannya tersebut Datuk Rar Jedau memutuskan untuk kembali. Kemudian dia berpesan kepada anaknya bahwa jika anaknya ingin bertemu dengannya, maka anak tersebut harus bernyanyi di tepi pantai. Maka dia akan datang menjenguk anaknya. Setelah berpesan kepada anaknya, Datuk Rar Jedau kembali berenang menuju Pulau Eno Karang.

\section{Dongeng tentang Hal-Hal Magis (Tales of Magic)}

Cerita-cerita yang termasuk dalam tipe ini yaitu cerita mengenai tantangan supranatural, istri atau suami atau kerabat supranatural, barang-barang magis, kekuatan atau pengetahuan supranatural, dan dongeng-dongeng tentang supranatural lainnya. Cerita-cerita yang termasuk dalam tipe ini yaitu:

1. Asal-Muasal Leukagotul

Leukagotul merupakan rumah adat masyarakat Desa Longgar. Menurut cerita, istilah kagotul berasal kata kago yang berarti kayu bakau. Kedatangan seorang perempuan yang hanyut dari Pulau Eno Karang sambil membawa kayu kago. Dia menancapkan kayu tersebut di daratan dan langsung membangun sebuah rumah. Ketika perempuan tersebut hanyut dari Pulau Eno Karang, dia hanya membawa kayu kago. Dia berniat di dalam hatinya, jika dia menemukan daratan, maka dia akan membangun sebuah rumah menggunakan kayu yang dibawanya tersebut.

Ketika dia tiba di Desa Longgar, dia langsung menancapkan kayu yang dibawanya tersebut. Setelah itu, dia membangun rumahnya secara lengkap. Hingga kini, rumah adat tersebut tetap dihuni oleh keturunan-keturunan dari moyang perempuan tersebut.

2. Asal-Muasal Kepulauan Aru

Kata Aru terdiri atas kata ar dan $u$, dan berasal dari bahasa Werka. $A r$ berarti kayu tikam-tikam (tombak), $u$ berarti dua 
buah. Terbentuknya Kepulauan Aru dilatarbelakangi pertengkaran yang terjadi antar dua saudara. Pada awalnya mereka tinggal berdampingan dengan baik di pulau Eno Karang. Kemudian mereka berselisih paham tentang kepemilikan dua kayu tikamtikam (tombak). Tombak tersebut digunakan untuk mencari hasil laut seperti ikan, penyu, teripang, dan lain sebagainya. Tombak tersebut bernama Arsemora (tombak emas) dan aregwadan (kayu nane laki-laki). Kedua kakak beradik tersebut bertarung memperebutkan Arsemora (tombak emas).Arsemona diyakini akan memberikan kesaktian bagi orang yang memilikinya. Selain itu, orang yang memilikinya akan mudah memperoleh tangkapan hasil-hasil laut. Karena adanya perselisihan tersebut, penghuni Pulau Eno Karang memohon kepada yang maha kuasa untuk menurunkan hujan, angin, badai, hingga terjadinya tsunami. Akibat bencana tersebut seluruh masyarakat Aru yang ada di pulau Eno Karan terpencar-pencar di pulau-pulau lainnya.

\section{Dongeng Realistis (Realistic Tales)}

Cerita-cerita yang termasuk dalam tipe ini meliputi cerita-cerita seperti seorang pemuda biasa menikahi putri raja, seorang wanita biasa menikah dengan pangeran, bukti kesetiaan dan kemurnian, istri yang keras kepala belajar menjadi setia, prinsipprinsip hidup yang baik, tindakan dan katakata yang cerdas, dongeng tentang nasib, perampok dan pembunuh, dan dongengdongeng realistik lainnya. Berdasarkan pengamatan, cerita-certa yang termasuk dalam tipe ini, yaitu

\section{Batu Kora}

Terjadinya Batu Kora akibat adanya pertarungan antara dua kakak beradik, yaitu Datuk Ursia dan Urlima. Keduanya saling menguji kesaktian yang mereka miliki. Mereka bedua berlomba-lomba untuk memecahkan sebuah batu. Mereka memulai perlombaan dari Pulau Babi, menuju Batu Kora. Hasil perlombaan tersebut yaitu yang berhasil memecahkan batu dan memenangkan perlombaan adalah Datuk Ursia (adik). Dia memecahkan batu dengan menggunakan kora-kora (perahu yang terbuat dari kayu) yang dimilikinya. Oleh karena itu, hingga saat ini batu tersebut disebut Batu Kora (batu yang dipecahkan oleh kora-kora).

2. Asal Muasal Hubungan Desa Apara dengan Werka (Beltubur)

Pada zaman dahulu, ketika peristiwa pecahnya pulau Eno, seluruh masyarakat terpecah-belah. Nenek moyang Pulau Werka pada awalnya tinggal di pulau yang berada di tanjung batu. Namun karena terjadi penambahan penduduk, nenek moyang Pulau Werka tinggal berpindah-pindah hingga akhirnya menetap di tempat yang sekarang ini. Untuk menemukan tempat yang sekarang ditinggali, para nenek moyang berjalan dengan seekor anjing. Anjing tersebutlah yang menemukan kampung yang sekarang ini. Ketika mereka sedang berjalan, mereka melihat ada seekor babi di dekat kolam. Babi tersebut ditangkap dan diikat kaki dan tangannya, kemudian dibakar. Tempat pembakaran babi tersebut hingga kini dijadikan tempat peringatan asal-mula kedatangan mereka.

Nenek moyang Desa Apara yang bernama Datuk Karkir datang ke Desa Beltubur untuk mencari makanan. Di sini mereka menemukan sagu tumang. Nenek moyang Desa Beltubur yang bernama Datuk Waili menerima Datuk Karkir dengan baik. Datuk Waili sebagai tuan rumah mengatakan kepada Datuk Karkir tidak usah mengambil sagu tumang, karena masyarakat Desa Beltubur akan menyiapkan sagu baru untuk mereka. Keesokan paginya masyarakat Desa Beltubur merobohkan satu atau dua pohon sagu untuk diberikan kepada datuk Karkir. Begitu seterusnya, hingga kini jika masyarakat Desa Apara datang ke Desa Beltubur, maka masyarakat Desa Beltubur akan menjamu mereka dan memberi oleh- 
oleh ketika mereka akan kembali ke Desa Apara.

\section{Cerita di Batu Goyang}

Terdapat satu marga yang bertugas untuk mencari ikan atau makanan bagi masyarakat Aru pada umumnya. Pada zaman dahulu ketika belum terdapat alat penerangan, orang-orang yang pergi melaut di malam hari berpesan kepada masyarakat untuk membuat api unggul di pinggir pantai sebagai tanda bahwa di situlah kampung mereka berada. Awalnya para nelayan hanya mencari ikan di dekat-dekat desa saja. Tetapi lama kelamaan mereka kehabisan ikan dikarenakan banyaknya jumlah orang yang harus dicukupi kebutuhan makannya. Maka para nelayan tersebut berlayar semakin ke tengah laut hingga jauh dari kampung. Agar tidak tersesat, mereka meminta para masyarakat desa untuk membuat api unggun di tepi pantai. Tetapi para nelayan tersebut terlalu jauh mencari ikan, sehingga api unggun yang ada di darat tidak tampak lagi. Para nelayan tersebut hanya melihat cahaya bintang yang ada di sebelah Barat. Sehingga untuk kembali ke kampung, mereka mengikuti bintang Barat tersebut. Setelah mengikuti cahaya bintang Barat, ternyata mereka sampai di pulau Banda Neira. Karena salah jalan, mereka berusaha untuk kembali. Dalam perjalanan pulang, para nelayan tersebut menurunkan marga Barens di pulau Wamar, dan marga Karaten di pulau Ngaibor. Setelah sampai ke kampung asalnya, mereka membagi hasil tangkapannya. Hasilnya berupa ikan Pari yang besar. Orang dari batas Joran sampai di Juri Mersim mendapat bagian sayap ikan. Sedangkan orang-orang di bagian Dobel, Desa Gwarjukur mendapat bagian ekor.

4. Pela Pinang antara Desa Beltubur dan Desa Lor-Lor

Pada zaman dahulu dikenal sistem barter. Orang-orang dari Desa Lor-lor membawa hasil kebunnya untuk ditukar dengan hasil-hasil kebun di desa-desa pesisir seperti Karey, Jorang, dan lain-lain. Ketika rombongan melewati pohon pinang yang sedang berbuah, secara tidak sengaja mereka berucap "pinang ini mirip perempuan Beltubur punya ujung susu". Rombongan yang datang dari Desa Lor-Lor berjumlah tiga puluh orang. Dari tiga puluh orang tersebut hanya seorang anak yatim yang tidak mengucapkan kata tersebut. dia malah menasehati dua puluh sembilan orang lainnya untuk tidak berbicara seperti itu. Dia khawatir jika ada masyarakat Desa Beltubur yang mendengar dan mersa tersinggung dengan perkataan tersebut.

Ternyata ada seorang nenek yang mendengar perkataan orang-orang dari Desa Lor-Lor. Nenek tersebut langsung menyampaikanhal-hal yang didengarnya kepada raja Hailip. Karena merasa marah, raja Hailip memerintahkan pasukannya untuk membunuh tiga puluh orang dari Desa Lor-Lor. Pasukan tersebut membunuh dua puluh sembilan orang dan hanya menyisakan satu orang anak yatim. Setelah membunuh dua puluh sembilan orang, pasukan berpesan kepada anak yatim tersebut untuk kembali ke desanya dan menceritakan kejadian yang sebenarnya terjadi. Setibanya di kampungnya, anak tersebut menceritakan peristiwa yang menimpa rombongannya kepada rajanya. Raja Lor-Lor merasa malu dan kembali datang ke Beltubur untuk meminta maaf, dan mengikrarkan hubungan pela pinang dengan masyarakat Desa Beltubur.

\section{Dongeng yang Memiliki Formula (Formula Tales)}

Formula tales meliputi dongengdongeng kumulatif (didasarkan pada jumlah, objek, binatang, atau nama; yang selalu dikaitkan dengan kematian, makanan, atau kejadian-kejadian lainnya), dongeng tentang jebakan, dan dongeng-dongeng formula lainnya. Cerita-cerita yang termasuk dalam tipe ini, yaitu

1. Sumur Keramat

Munculnya sumur keramat yang ada di Desa Longgar bermula dari adanya 
perpecahan pulau Eno Karang. Ketika semua orang sudah pergi dari Pulau Eno Karang, terdapat seorang datuk yang sangat sakti. Dia mampu melangkahkan kakinya dari pulau Eno Karang ke tempat sumur keramat tersebut. Karena kesaktiannya tersebut, dia mampu meletakkan satu kakinya di pulau Eno Karang, sedangkan kaki lainnya di tempat sumur keramat. Datuk tersebut rasa sedih karena melihat masyarakat yang mengungsi dari Pulau Eno Karang tidak membawa air bersih. Oleh karena itu dia mengambil air menggunakan tempurung kelapa lalu menyiram kakinya yang berada di tempat sumur keramat. Dengan adanya kejadian tersebut maka muncullah air dari dalam tanah dan hingga saat ini air tersebut masih digunakan masyarakat Desa Longgar untuk memenuhi kebutuhan air bersih.

\section{Asal-Muasal Nama Desa Koba}

Kata Koba memiliki arti malapo atau melepuh. Disebut Koba (Malapo) karena Datuk yang berasal dari Desa Koba terkena air panas. Dalam perjalanan Datuk Ursia dan Urlima dengan menggunakan sebuah belang (perahu khas masyarakat Aru) yang bernama Nawam Ursia, datuk yang berasal dari Desa Koba dalam belang tersebut bertugas untuk memasak. Suatu ketika, Datuk Koba terkena air panas yang tumpah. Karena peristiwa tersebut datuk Ursia dan Urlima menurunkan Datuk Koba di sebuah sungai, yaitu sungai Martaning (sungai asli).

Datuk Koba diturunkan di tengah wilayah kekuasaan datuk Ursia dan Urlima. Datuk Koba ditugaskan untuk menjaga pintu atau kunci antara dua kubu masyarakat Koba. Selain itu, Datuk Koba juga ditugaskan untuk memberi makan masyarakat Ursia dan Urlima. Masyarakat Koba tidak memiliki petuanan laut, tetapi bisa mengambil hasil di semua petuanan laut yang ada di Aru. Hal tersebut bertujuan jika ada masyarakat yang berasal dari Ursia dan Urlima yang sedang lewat di depan Desa Koba, kemudian mereka merasa lapar atau butuh perlindungan, maka seluruh masyarakat Desa Koba dengan senang hati menerima mereka. Pesan tersebut hingga saat ini diturunkan secara turun-temurun hingga saat ini.

\section{B. Motif Cerita}

Berdasarkan data yang terdapat dalam penelitian ini, cerita-cerita rakyat dikelompokkan dalam beberapa motif berikut.

\section{Motif Benda}

Cerita-cerita rakyat yang termasuk dalam motif benda adalah: (1) Batu Kora; (2) Asal-muasal hubungan Desa Apara dengan Werka (Beltubur); (3) Asal-muasal nama Desa Koba; (4) Datuk Rar Jedau; (5) Pela pinang antara Desa Beltubur dengan Lor-Lor; (6) Sumur keramat; (7) AsalMuasal Leukagotil; dan (8) Asal-Muasal Kepulauan Aru.

\section{Motif Suatu Konsep}

Cerita-cerita rakyat yang termasuk dalam motif suatu konsep adalah: (1) Asalmuasal hubungan Desa Apara dengan Werka (Beltubur); dan (2) Pela pinang antara Desa Beltubur dengan Lor-Lor.

\section{Motif Suatu Perbuatan}

Cerita-cerita rakyat yang termasuk dalam motif suatu perbuatan adalah: (1) Batu Kora; (2) Asal-Muasal hubungan Desa Apara dengan Werka (Beltubur); (3) AsalMuasal nama Desa Koba; (4) Cerita di Batu Goyang; (5) Asal-muasal Leukagotul; (6) Asal-muasal Desa Longgar; dan (7)Asalmuasal Kepulauan Aru.

\section{Motif Tipe Orang Tertentu}

Cerita rakyat yang termasuk dalam motif Tipe Orang Tertentu hanya satu, yaitu Datuk Rarjedau.

\section{PENUTUP}

Kekayaan cerita rakyat yang dimiliki desa-desa di Kabupaten Kepulauan Aru sangat beragam. Namun pemerintah daerah belum memberikan perhatian khusus dalam 
menginventarisasi cerita-cerita rakyat ada. Setelah melakukan proses pengumpulan data di lapangan, peneliti bertemu masyarakatmasyarakat yang sangat menjunjung adat istiadat. Agak sulit memperoleh cerita-cerita rakyat yang dianggap sakral. Mereka merasa tabu untuk mengungkapkan sejarah desa atau cerita-cerita lainnya. Adanya sikap tertutup tersebut dikarenakan adanya sumpah yang mengikat, dan cerita-cerita rakyat yang ada hanya boleh dituturkan oleh orang-orang tertentu saja.

Berdasarkan hasil inventarisasi yang telah dilakukan, terdapat sembilan cerita rakyat. Jumlah tersebut dapat bertambah, jika memperluas wilayah penelitian. Kesembilan cerita rakyat tersebut kemudian dikelompokkan berdasarkan tipe dan motif. Hasil yang diperoleh yaitu terdapat empat tipe yaitu Animals Tales, Tales of Magic, Realistic Tales, dan Formula Tales. Tipetipe yang tidak termasuk dalam penelitian ini yaitu Religious Tales, Tales of The Stupid Ogre/Giant/Devil, Anecdotes and Jokes, dan Formula Tales.

Selain itu, dari enam motif cerita yang dikemukakan oleh Taum, terdapat empat motif cerita yaitu motif benda, motif suatu konsep, motif suatu perbuatan, dan motif tipe orang tertentu. Motif yang belum ditemukan yaitu motif berupa hewan yang luar biasa, dan motif tentang penipuan terhaap suatu tokoh.

Melalui pemaparan-pemaparan tersebut, dapat disimpulkan bahwa tidak semua tipe dan motif cerita rakyat dapat dijumpai di dalam cerita rakyat Kabupaten Kepulauan Aru. Tidak menutup kemungkinan, jika penelitian ini dilakukan lebih mendalam pada kecamatan-kecamatan lainnya di Kabupaten Kepulauan Aru, maka cerita-cerita rakyat Kabupaten Kepulauan Aru dapat mesuk dalam tipe dan motif yang dipaparkan oleh mazhab Finlandia.

Penelitian tipe dan motif di Kabupaten Kepulauan Aru menyimpan potensi yang besar. Wilayah Kabupaten Kepulauan Aru yang desa-desanya hanya dapat dijangkau menggunakan transportasi laut memberikan tantangan tersendiri. Penulis belum mampu menjangkau seluruh kecamatan yang ada di Kabupaten Kepulauan Aru. Oleh karena itu, penulis menyarankan untuk penelitian berikutnya melakukan penginventarisasian cerita-cerita rakyat di kecamatan Aru Selatan Utara, Aru, Selatan, Aru Utara, Aru Utara Timur Batuley, Pulau-Pulau Aru, dan Sir-Sir. Di kecamatan-kecamatan tersebut masih terdapat berbagai macam cerita rakyat yang dapat diinventarisasi dan menarik untuk dianalisis.

\section{DAFTAR PUSTAKA}

A. P. c Sool. 2009. Sejarah Gereja Katolik di Kepulauan Aru. Yogyakarta: Kanisius.

Ferdinandus, P., \& Erwin S. Kembaren. 2016. "Tipe dan Motif dalam Cerita Rakyat Lor". Jurnal Matra Sastra, Vol.3, No.1, Edisi Juni 2016. hlm. 89-109.

Danandjaja, James. 2007. Folklor Indonesia Ilmu Gosip, Dongeng, dan LainLain. Jakarta: Pustaka Utama Grafiti.

Endraswara, Suwardi. 2009. Metodologi Penelitian Folklor. Jakarta: Medpress.

MPSS, Pudentia. 2015. Metodologi Kajian Tradisi Lisan. Jakarta: Yayasan Pustaka Obor Indonesia.

Ratna Nyoman Kuta. 2010. Metodologi Penelitian Kajian Budaya dan Ilmu Sosial Humaniora pada Umumnya. Yogyakarta: Pustaka Pelajar.

Sayuti, Suminto. 2011. Studi Sastra: Konsep Dasar Teori dan Penerapannya dalam Karya Sasta. Yogyakarta: Gama Media.

Sugiyono. 2009. Metode Penelitian Kuantitatif, Kualitatif, dan $R \& D$. Bandung: Alfabeta.

Taum, Yoseph Yapi. 2011. Studi Sastra Lisan: Sejarah, Metode, dan Pendekatan Disertasi Contoh 
Totobuang, Vol. 5, No. 2, Juni 2017: 137-148

Penerapannya. Yogyakarta: Lamalera.

Taum, Yoseph Yapi. 2016. "Madzab Finlandia". dalam Pelatihan Pemetaan Sastra. Diselenggarangkan oleh Balai Bahasa Jawa Tengah. Semarang, 21-24 Maret 2016.

Wakim, Mezak. 2014. "Garis Wallace dan Kepulauan Aru: Tinjauan SosioHistoris". Jurnal Penelitian, Vol.8,
No.6, Edisi Desember 2014. hlm. 102-115.

Wempi, Darmapan. 2012. "Letay sebagai Kearifan Lokal Masyarakat Aru" dalam Dialog Budaya Daerah Maluku 2012. Diselenggarakan oleh BPNB Ambon.

Wellek dan Warren. 2014. Teori Kesusastraan. Jakarta: Gramedia Pustaka Utama. 